\title{
Screening of Extracellular Keratinase Producing Bacteria from Feather Processing Areas in Vellore, Tamil Nadu, India
}

\author{
H. Prasad V, G. Kumar, Karthik L, and B. Rao KV* \\ Molecular and Microbiology Research Lab, Environmental Biotechnology Division, School of \\ Bio Sciences and Technology, VIT University, Vellore, Tamil Nadu-632 014, India
}

Received 11 March 2010, accepted in revised form 24 June 2010 (revised further: 16 May 2011)

\begin{abstract}
The aim of the current study was to isolate keratinolytic bacteria from the soil samples collected from different feather processing areas in Vellore, TN, India. The isolation was performed by serial dilution and spread plat method. Total eight bacteria were isolated from the collected soil samples. All isolates were screened for keratinolytic activity by Casein agar plate method, among eight bacterial isolates only one (H5) isolate showed the keratinolytic activity in Casein agar medium. H5 isolate (potential strain) was identified as Bacillus sp. by microscopic and biochemical experiments. The best enzyme activity was observed at $\mathrm{pH} 7$ and temperature $30^{\circ} \mathrm{C}$.
\end{abstract}

Keywords: Keratinolytic; Spread plate method; Bacillus sp.; Bacteria.

(c) 2010 JSR Publications. ISSN: 2070-0237 (Print); 2070-0245 (Online). All rights reserved.

DOI: 10.3329/jsr.v2i3.4567 J. Sci. Res. 2 (3), 559-565 (2010)

\section{Introduction}

Keratin is an insoluble protein macromolecule with very high stability and low degradation rate. Keratin is mainly present in hair, feather, nails, wool and horns [1]. High protein content of keratin waste can be used as a good source of protein and amino acids by systemic recycling. Recycling of feather can provides a cheap and alternative protein feed stuff. Further this can be used for animals feed and for many other purposes. However, poor digestibility of keratin is a problem in recycling [2-4].

Keratinase is an extracellular enzyme used for the bio degradation of keratin. Keratinase is produced only in the presence of keratin substrate. Keratinase attacks the disulfide bond of keratin to degrade it. Some microbes have been reported to produce keratinase in the presence of keratin substrate. Keratinase producing microorganisms have ability to degrade chicken feathers, hair, nails, wool etc. [5, 6]. Several keratinolytic microorganisms have been isolated and characterized from soil collected nearby feather

\footnotetext{
*Corresponding author: kokatibhaskar@yahoo.co.in
} 
processing units includes Bacteria, Bacillus Sp. FK46, B. licheniformis, B. pumilus sps, Vibrio sps strain Kr2, Actinobacteria, Streptomyces pactum, S. albus, and Saprophytic and Dermatophlilic fungi, Aspergillus sps, Rhizomucor sps, Trichophyton mentagrophytes, $T$. rubrum, T. gallinae, Microsporum canis and M. gypseum [7-10].

In the current study we focused on the isolation and characterization of extracellular keratinase producing bacteria from the soil of feather processing units in Vellore, TN, India.

\section{Materials and Methods}

\subsection{Sample collection}

The soil samples were collected from the feather processing areas from Vellore, TN, India, during December 2008. Soil samples were collected from 3 to $4 \mathrm{~cm}$ depth and transferred in sterile plastic bags. The samples were brought to Molecular and Microbiology Research Lab, VIT University, Vellore, TN, India for further processing.

\subsection{Isolation of bacteria}

Isolation of bacteria was performed by serial dilution and plating method on nutrient agar medium (NAM). One gram of soil sample was transferred in $10 \mathrm{ml}$ of sterilized distilled water and mixed properly. Serial dilution was made up to $10^{-6} .0 .1 \mathrm{ml}$ of the diluted sample was inoculated in the NAM plates from each dilution. The Petri plates were rotated clockwise and anticlockwise to spread the sample uniformly. Plates were incubated at $37^{\circ} \mathrm{C}$ for 24 to 48 hours. The bacterial isolates were further sub cultured on NAM to obtain pure culture. Pure isolates were maintained in NAM slants at $4^{\circ} \mathrm{C}$ for further studies [11].

\subsection{Screening of keratinolytic bacteria}

The bacterial isolates were inoculated in the basal medium enriched with chicken feather waste. The $\mathrm{pH}$ was adjusted to 8.0. The medium was incubated in a rotary shaker at a speed of $150 \mathrm{rpm}$ for $37^{\circ} \mathrm{C}$ for 24 hours. After incubation, the cells were removed by centrifugation at $10,000 \mathrm{rpm}$ for 10 minutes and the supernatant was collected and examined for enzyme activity.

\subsection{Enzyme activity}

The Casein agar plates were prepared, wells were made in the agar surface using sterilize gel borer, and $10 \mu \mathrm{l}$ cell free supernatant was transferred in to the well using a micropipette. The plates were incubated at $37^{\circ} \mathrm{C}$ for 24 hours. The plates were observed for zone of hydrolysis [6]. 


\subsection{Characterization and identification of keratinolytic bacteria}

\subsubsection{Cultural characterization}

The isolates were observed under the microscope, the colony morphology was noted with respect to color, shape, size, nature of colony and pigmentation [12].

\subsubsection{Microscopic observation}

The bacterial isolates were Gram stained and observed under a high power magnifying lens in light microscope. Endospore staining and motility test were perform to observe the morphology and motility of the cells [12].

\subsubsection{Biochemical characterization}

The bacterial isolates were characterized biochemically by indole test, methyl red test, voges proskauer test, Simmons citrate test, catalase test, oxidase test, urease test, nitrate reduction test, gelatin hydrolysis test, Starch hydrolysis test, $\mathrm{H}_{2} \mathrm{~S}$ production and carbohydrate fermentation test (glucose, sucrose and lactose) [12].

\subsection{Keratinolytic activity assay}

$20 \mathrm{ml}$ of $0.1 \mathrm{~mol}^{-1}$ Tris buffer ( $\mathrm{pH}$ 8) containing $0.1 \%$ feather and $40 \mu \mathrm{l}$ of enzyme solution was taken and was incubated for 30 minutes at $55^{\circ} \mathrm{C}$. The reaction was stoped with $500 \mu \mathrm{l} 0.1 \mathrm{l} \mathrm{mol}^{-1}$ trichloroacetic acid (TCA) in $0.1 \mathrm{~mol}^{-1}$ Tris buffer, $\mathrm{pH}$ 8. The amino acid liberated were measured as the absorbance at $590 \mathrm{~nm}$ against a reagent blank and the quantity was determined from a standard tyrosine solution (50-500 $\mu \mathrm{g} \mathrm{ml}^{-1}$ ) using a spectrophotometer [13].

\subsubsection{Effect of $p H$}

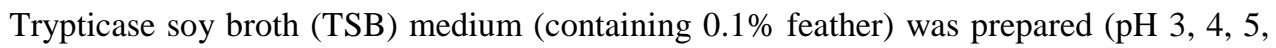
6, 7 and 8). The bacterial isolate was inoculated in to the TSB medium. Inoculated mediums were incubated at $37^{\circ} \mathrm{C}$ for 48 hours. Absorbance of the medium was measured using spectrophotometer at $590 \mathrm{~nm}$ against the TSB as blank [14].

\subsubsection{Effect of temperature}

TSB medium was prepared and the bacterial cultures were inoculated into the TSB medium (containing $0.1 \%$ feather). The inoculated media were incubated at $4,25,30,35$, 40 and $45^{\circ} \mathrm{C}$. The aabsorbance of the medium was measured using spectrophotometer at $590 \mathrm{~nm}$ against the TSB as blank [14]. 


\section{Result and Discussion}

Keratin is a strong protein find in skin, hair, nails, horns, teeth. Keratin is difficult to dissolve due to the presence of cysteine disulfide that can form disulfide bridges. These disulfide bridges create an extremely strong helix shape. Microorganisms can degrade the keratin by the production of keratinase (an extracellular enzyme). Some bacteria, actinobacteria and fungi are reported to carry keratinolytic activity. In the current study eight bacteria were isolated from the soil samples collected from different feather processing areas in Vellore, TN, India, the isolates were named H1, H2, H3, H4, H5, H6, $\mathrm{H} 7$ and $\mathrm{H} 8$.

All the isolates (H1 to H8) were screened for keratinolytic activity on the Casein agar plates. The organisms producing zone of hydrolysis Casein agar plates were considered as keratinolytic organisms. Among all, only H5 isolate showed zone of hydrolysis while other isolates didn't show any zone. The keratinolytic activity of H5 isolate is mentioned in Fig. 1. The H5 isolate produced $26 \mathrm{~mm}$ zone of inhibition on Casein agar plates.

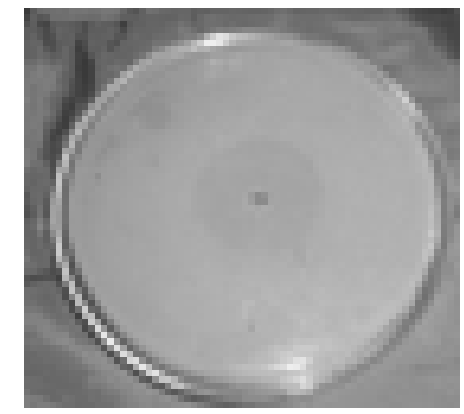

Fig. 1. Keratinolytic activity of H5 isolate.

The colony morphology of H5 organisms is reported in Fig. 2 and Table 1. The colonies of H5 isolates were found as Large, round, irregular, mucoid, creemy white in colour, raided.

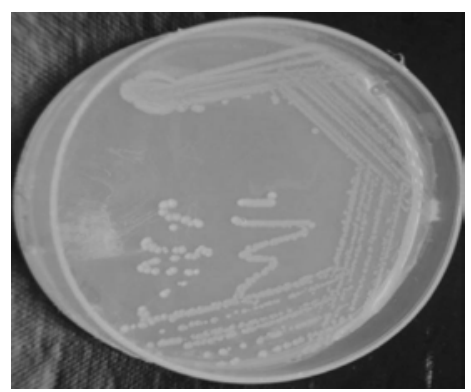

Fig. 2. Colony morphology of H5 isolate. 
Results for the identification and characterization of the H5 (potential isolate) isolate are presented in the Table 1. The cultural, microscopically and biochemical experiments suggests the isolate as Bacillus sp [15]. Previous studies conducted for the isolation of keratinolytic organism from soil and other natural sources, reports Bacillus sp. as a potential keratinolytic organism and its possible use in field studies for biodegradation of feather in feather processing units [16-17].

Table 1. Characterization of keratinolytic bacteria (H5 isolate).

\begin{tabular}{lll}
\hline & Characterization of bacteria & Result \\
\hline Cultural characters & Colony morphology & $\begin{array}{l}\text { Large, round, irregular, mucoid, } \\
\text { fast growing colonies }\end{array}$ \\
Microscopic characters & Spore staining & $\begin{array}{l}\text { Spore forming } \\
\text { Gram staining }\end{array}$ \\
& Motility & Non mositive rods \\
& Indole & Negative \\
Biochemical characters & Methyl Red & Negative \\
& Voges Proskauer & Positive \\
& Citrate utilization & Positive \\
& Catalase & Positive \\
& Oxidase & Negative \\
& Urease & Negative \\
& Nitrate reduction & Positive \\
& Gelatin liquefaction & Positive \\
& Starch hydrolysis & Positive \\
& Hydrogen sulphide & Negative \\
& Glucose & Positive \\
& Sucrose & Positive \\
& Lactose & Negative \\
\hline
\end{tabular}

Table 2. Effect of different pH on enzyme activity.

\begin{tabular}{lllllll}
\hline Bacterial isolate (H5) & \multicolumn{7}{c}{ OD value at 590 nm } \\
\cline { 2 - 7 } & $\mathrm{pH} \mathrm{3}$ & $\mathrm{pH} \mathrm{4}$ & $\mathrm{pH} \mathrm{5}$ & $\mathrm{pH} \mathrm{6}$ & $\mathrm{pH} \mathrm{7}$ & $\mathrm{pH} 8$ \\
\hline Bacillus sp & 0 & 0.005 & 0.014 & 0.075 & 0.099 & 0.065 \\
\hline
\end{tabular}

Table 3. Effect of different temperature on enzyme activity.

\begin{tabular}{llllllll}
\hline Bacterial isolate (H5) & \multicolumn{7}{c}{ OD value at $590 \mathrm{~nm}$} \\
\cline { 2 - 8 } & $4^{\circ} \mathrm{C}$ & $25^{\circ} \mathrm{C}$ & $30^{\circ} \mathrm{C}$ & $35^{\circ} \mathrm{C}$ & $40^{\circ} \mathrm{C}$ & $45^{\circ} \mathrm{C}$ & $50^{\circ} \mathrm{C}$ \\
\hline Bacillus sp. & 0 & 0.194 & 0.950 & 0.900 & 0.845 & 0.354 & 0 \\
\hline
\end{tabular}


Keratinase enzyme activity was optimized with respect of $\mathrm{pH}$ and temperature. The results for $\mathrm{pH}$ effect are mentioned in Table 2 and Fig. 3. The results for temperature are mentioned in Table 3 and Fig. 4. $\mathrm{H} 5$ isolate showed best enzyme activity at $\mathrm{pH} 7$ and temperature $30^{\circ} \mathrm{C}$.

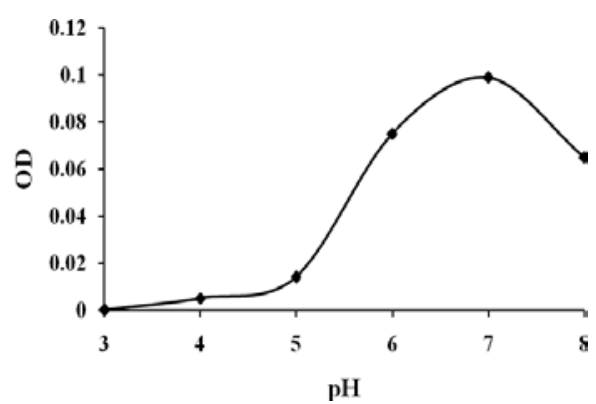

Fig. 3. Effect of $\mathrm{pH}$ on enzyme activity.

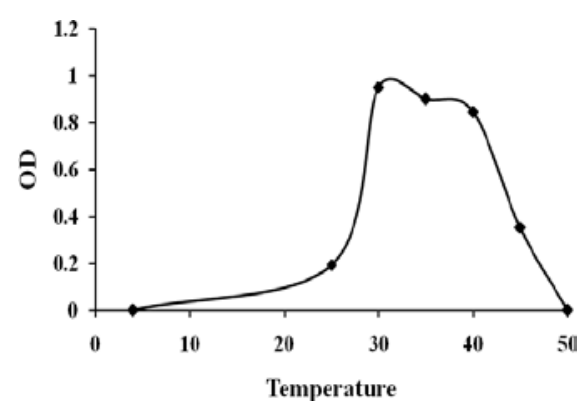

Fig. 4. Effect of temperature on enzyme activity.

Results of this study indicate that the $\mathrm{H} 5$ isolate is a potential keratinolytic organism and can be used for the biodegradation of keratin in feather industries.

\section{Acknowledgements}

Authors wish to thank management of VIT University, Vellore, TN, India, for providing necessary facilities and support for the completion of this work.

\section{References}

1. A. A. Onifade, N. A. Al-Sane, A. A. Al Musallam, and S. Al-Zarban, Bioresource Tech. 66, 1 (1998). doi:10.1016/S0960-8524(98)00033-9

2. H. Takami, N. Satoshi, R. Aono, and K. Horikoshi, Biosci. Biotech. and Biochem. 56, 1667 (1992). doi:10.1271/bbb.56.1667

3. C. G. Lee, P. R. Ferket, and J. C. H. Shih, Fed. Am. Soc. Experimental Biology J. 5, A596 (1991).

4. C. M. Williams, C. G. Lee, J. D. Garlich, and J. C. H. Shih, Poultry Science 70, 85 (1991).

5. H. Gradišar, J. Friedrich, I. Križaj and R. Jerala, Appl. Environ. Microbio. 71, 3420 (2005). doi:10.1128/AEM.71.7.3420-3426.2005 ; PMid:16000744, PMCid:1168971

6. C. Cai, B. Lou, and X Zheng, J. Zhejiang Univ. Science B 9, 60 (2008). doi:10.1631/jzus.B061620; PMid:18196614, PMCid:2170470

7. W. Suntornsuk and L. Suntornsuk, Biosource Tech. 86, 239 (2003). doi:10.1016/S0960-8524(02)00177-3

8. H. Kormaz, H. Hur and S. Dincer, Annals of Microbiology 54, 201 (2004).

9. H. A. El-Refai, M. A. Abdel Naby, A. Gaballa, M. H. El-Araby, and A. F. Abdel Fattah, Process Biochemistry 40, 2325 (2005). doi:10.1016/j.procbio.2004.09.006 
10. J. Fridrich, H. Gradisar, D. Mandin, and J. P. Chaumont, Letter in Applied Microbiology 28, 127 (1999). doi:10.1046/j.1365-2672.1999.00485.x

11. L. Karthik, Gaurav Kumar, and K. V. Bhaskara Rao, Int. J. Pharm. Pharmaceut. Sci. 2, 199 (2010).

12. J. G. Cappuccino and N. Sherman, Microbiology: A Laboratory Manual (Benjamin-cummings Publishing Company, New York, 1996).

13. R. Alessandro and B. Adriano, Brazilian J. Microbiology 37, 395 (2006).

14. P. Tamilmani, A. Umamaheswari, A. Vinayagam, and B. Prakash, Int. J. Poultry Sci. 7, 184 (2008). doi:10.3923/ijps.2008.184.188

15. R. E. Buchanan, N. E. Gibbons, Bergey' s manual of determinative bacteriology, 8th edn. (The Williams and Wilkins Co., Baltimore, 1974)

16. X. Lin, D. W. Kelemen, E. S. Miller, and J. C. H. Shih, Appl. Environ. Microbiol. 61, 1469 (1995). PMid:7747965 PMCid:167403

17. J. M. Kim, W. J. Lim, and H. J. Suh, Process Biochem. 37, 287 (2001). doi:10.1016/S0032-9592(01)00206-0

18. P. Geun-Tae and S. Hong-Joo, Microbio. Res. 164, 478 (2009). doi:10.1016/j.micres.2007.02.004 ; PMid:17459685 